for the greater part of its length. Their Eustachian tube also presents no unusual features, but I have not so far been able to examine it in the sperm.

Obliteration of the meatal lumen in sperm whales must occur somewhere in the middle region of the canal, since dissection with steam-saw and axe reveals that the proximal portion, running in the temporal bone, is still intact. Also, in two physically immature adults examined, the external meatus, after termination of its cavity, was prolonged into a short solid stalk representing the canal after obliteration of its lumen. This suggests that the fœtal condition may exhibit a continuous meatus, but unfortunately sperm fœetuses are not available in the Antarctic.

There is evidence that the sperm whale dives to great depths, and it is apparent that permanent closure of the external auditory meatus has adaptive advantage in this cetacean, which must be capable of tolerating considerable changes in hydrostatic pressure.

The adult sperm whale can thus only hear by penetration of vibrations through the solid tissues of the head. In a mammal this does not appear an efficient path; but in the light of Dr. Fraser's remarks on the sensitivity of dolphins to supersonic emissions, it seems clear that such vibrations of high frequency and short wave-length would suffer considerably less absorption, during direct transmission through the sperm head, than sounds within the auditory range.

The experience of whaling gunners in catchers fitted with 'Asdic' gear shows that the larger rorquals, as well as dolphins, are, in fact, sensitive to supersonic vibrations. The 'ping' not only locates but also frightens the whale, which makes off at speed. This becomes an advantage should the catcher be fast enough to overtake its quarry, because when blue and fin whales are running they blow more often and are therefore more easily followed; moreover, they are sooner exhausted. The deliberate working of the 'Asdic' at 'short-interval transmission' to keep whales on the run has, in fact, been employed success. fully in chasing.

I am indebted to both Messrs. Chr. Salvesen and Co. and to the Discovery Investigations for facilities enjoyed in the south.

On board Fl/F. Southern Harvester,

\section{Robert Clarke}

c/o Messrs. Chr. Salvesen and Co., 29 Bernard Street,

Leith.

Feb. 12.

\section{A Plant Disease Caused by a Spore-forming Bacterium under Natural Conditions}

Tнат spore-forming bacteria, that is, species of the genus Bacillus, are responsible for some plant diseases has been recorded from time to time, but has rarely been confirmed; it is not yet generally accepted, as the great majority of bacterial plant diseases are known to be due to bacteria which do not form spores.

A few years ago, one of us (W. J. D.) recorded ${ }^{1}$ the complete disintegration, under laboratory conditions, of the parenchyma of whole, or slices, of potato tubers, carrots, onions, cucumbers and iris stems by Bacillus polymyxa (Prazmowski) Migula, a soilinhabiting organism. Madhok and Fazal-ud-Din ${ }^{2}$ investigated a disease of tomato fruits which was also shown to be due to a species of Bacillus which

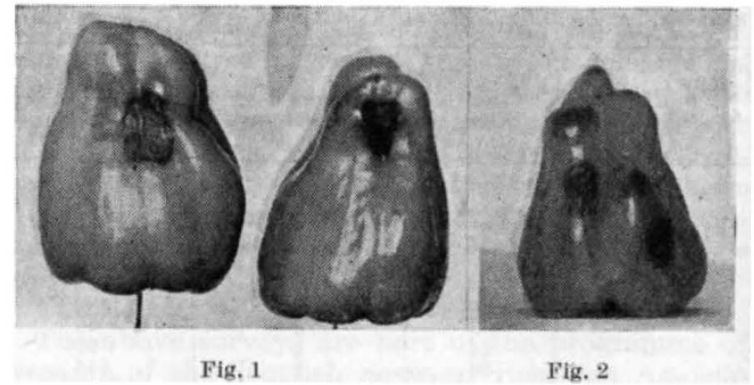

Fig. 1. ORIGINAL FRUITS BROJGHT FROM THE SOUTh OF PALESTINE. Fig. 2. INFEOTION EXPERIMENT ON GREEN PEPPER FRUITS WITH THE ORGANISM ISOLATED FROM MATERIAL FROM THE SOUTH OF PaLestine

they named $B$. fructodestruens, and the subject was further reviewed a few years later ${ }^{3}$.

Quite recently, one of us (Z. V.) has investigated a widespread fruit-spot of green pepper (Capsicum annuum) in Palestine, which was shown to be caused by a spore-forming bacterium identified at Cambridge as $B$. polymyxa. On the maturing fruits spots developed, one to five in number, light brown to grey, soft or firm, varying in size from $8 \mathrm{~mm}$. to $12 \mathrm{~mm}$. (Fig. 1). Microscopic examination of the softened tissues underlying the spots revealed the presence of numerous rod-shaped bacteria which were isolated in pure culture and produced subterminal spores. 48-Hour broth cultures were pasteurized at $85-90^{\circ} \mathrm{C}$. for $10 \mathrm{~min}$. and were used to establish cultures on potato dextrose agar from which suspensions in water were used for a series of infection experiments. Drops of the suspension were deposited on the surface of Capsicum fruits, which were then wounded by needle pricks. The inoculated fruits, placed under bell-jars over water, at room temperature $\left(28-30^{\circ} \mathrm{C}.\right)$, developed lesions similar to those observed in the field (Fig. 2).

The organism was re-isolated from these spots, and the infection experiments were repeated with the re-isolated organism with like results. Controls pricked through drops of sterile distilled water did not develop any sort of infection. Various vegetables inoculated with the organism, under laboratory conditions, developed a typical soft rot of the parenchyma; but no infection of Capsicum was obtained either by spraying on a suspension of the bacteria or by inoculating wounds on leaves. This last observation is in agreement with that made at Cambridge with another strain of $B$. polymyxa, used to inoculate stems of iris and tomato plants which did not become infected, although kept under moist conditions and at a relatively high temperature.

It appears, therefore, that under natural conditions, involving high humidity and a relatively high $\left(28-30^{\circ}\right.$ C.) temperature, the spore-former, Bacillus polymyxa, is a wound parasite, able to disintegrate the parenchyma of Capsicum fruits by means of its pectic enzymes.

Division of Plant Pathology,

\section{Z. VOLCANI}

Agricultural Research Station, Rehovot, Palestine.

\section{W. J. Dowson}

Botany School, Cambridge.

1 Dowson, W. J., Nature, 152, 331 (1943).

Madhok, M. R., and Fazal-ud-Din, Indian J. Agric. Sci., 13, 129 (1943).

s Dowson, W. J., Nature, 154, 557. (1945). 